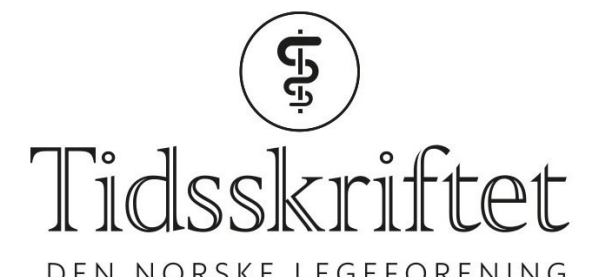

DEN NORSKE LEGEFORENING

\title{
Tuberkulose og krigstid
}

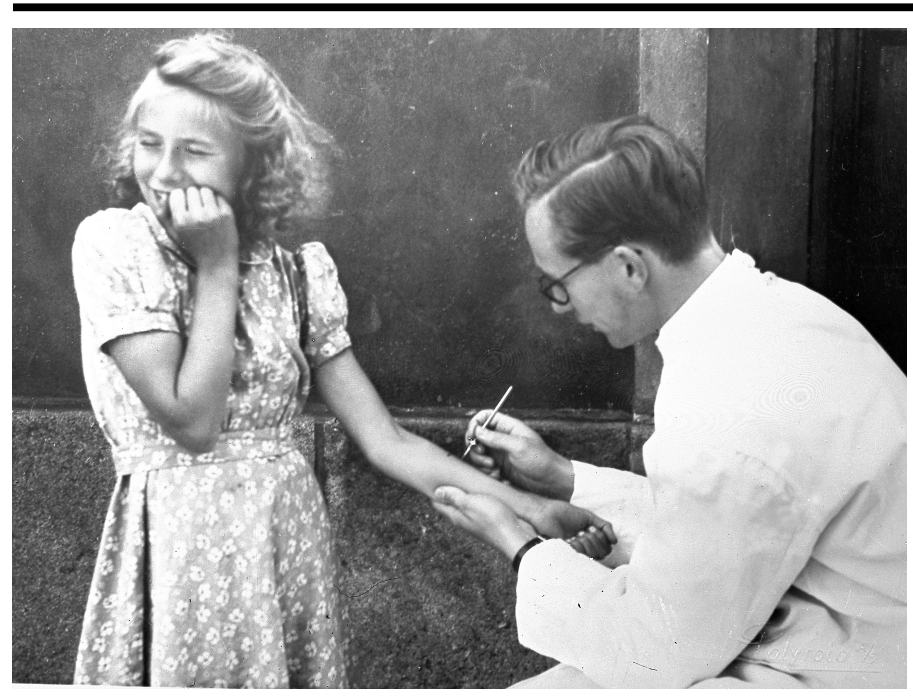

TIDLIGERE I TIDSSKRIFTET

TONE BERGSET

E-post: tone.bergset@legeforeningen.no

I 1942 var det ikke bare krigen som herjet, men også tuberkulosen. Det hastet med å opprette flere diagnosestasjoner, og desentralisering av tuberkulosearbeidet var viktig - en motsats til i dag hvor søkelyset er rettet mot sentralisering av helsearbeidet (Tidsskr Nor Lægeforen 1942; 62: 366-68).

Plan over diagnosestasjoner i Norge. 


\begin{tabular}{|c|c|c|c|c|}
\hline \multirow{2}{*}{ Fylker } & \multicolumn{2}{|r|}{ Nåværende diagnosestasjoner } & \multicolumn{2}{|c|}{ Planlagte diagnosestasjoner } \\
\hline & $\begin{array}{l}\text { An- } \\
\text { tall }\end{array}$ & Sted & \begin{tabular}{|l|l} 
An- \\
tall
\end{tabular} & Sted \\
\hline Oslo og Bergen .. & 2 & $\begin{array}{l}1 \text { stasjon } \mathrm{i} \text { hver av disse } \\
\text { byer (helserádene). }\end{array}$ & 0 & \\
\hline Akershus. . & 1 & 1 stasjon i Oslo. & 3 & $\begin{array}{l}\text { Glittre san., Lille- } \\
\text { strøm, Eidsvoll. }\end{array}$ \\
\hline Hedmark ....... & 2 & Kongsvinger og Hamar. & 3 & $\begin{array}{l}\text { Tynset, Elverum, } \\
\text { Moelv. }\end{array}$ \\
\hline Opland .. & 4 & $\begin{array}{l}\text { Dokka, Gjøvik, Lille- } \\
\text { hammer, Follebu. }\end{array}$ & 1 & Otta eller Dombås \\
\hline Østfold & 7 & $\begin{array}{l}2 \text { i Moss, Mysen, Sarps- } \\
\text { borg, } 2 \text { i Fredrikstad, } \\
\text { Halden. }\end{array}$ & 0 & \\
\hline Buskerud . & 3 & $\begin{array}{l}\text { Drammen, Kongsberg, } \\
\text { Amot. }\end{array}$ & 2 & $\begin{array}{l}\text { Hønefoss, Nes- } \\
\text { byen (?). }\end{array}$ \\
\hline Vestfold . & 3 & $\begin{array}{l}\text { Tønsberg, Holmestrand, } \\
\text { Sandefjord. }\end{array}$ & 2 & Larvik, Horten. \\
\hline Telemark ... & 3 & $\begin{array}{l}\text { Skien, Notodden, } \\
\text { Kragerø. }\end{array}$ & 2 & $\begin{array}{l}\text { Tinn (Rjukan), } \\
\text { Kviteseid. }\end{array}$ \\
\hline Aust-Agder. & 4 & $\begin{array}{l}\text { Risør, Landeskogen, } \\
\text { Arendal, Grimstad. }\end{array}$ & 0 & \\
\hline Vest-Agder & 2 & Kristiansand, Mandal. & 1 & Flekkefjord. \\
\hline Rogaland .. & 4 & $\begin{array}{l}\text { Sand, Haugesund, } 2 \text { i } \\
\text { Stavanger. }\end{array}$ & 1 & Egersund. \\
\hline Hordaland ....... & 7 & $\begin{array}{l}\text { Voss, Ølen, Nesttun, Lak- } \\
\text { sevág, Bergen (2 for } \\
\text { fylket), Jondal (Odda). }\end{array}$ & $\begin{array}{l}1 \\
1\end{array}$ & Lindås. \\
\hline Sogn og Fjordane & 5 & $\begin{array}{l}\text { Lavik, Florø, Måløy, } \\
\text { Gloppen, Lyster san. }\end{array}$ & 0 & \\
\hline Møre og Romsdal. & 3 & $\begin{array}{l}\text { Alesund, Molde, Kristi- } \\
\text { ansund. }\end{array}$ & 2 & Volda, Tingvoll. \\
\hline Sør-Trøndelag ... & 14 & $\begin{array}{l}\text { Ringvål san., } 1 \text { for Trond- } \\
\text { heim (for byen), Afjord, } \\
\text { Rissa, Frøya, Hemne, } \\
\text { Orkdal, Meldal, Renne- } \\
\text { bu, Opdal, Singsas, Sel- } \\
\text { bu, Alen, Røros. }\end{array}$ & 1 & $\begin{array}{l}\text { Ny stasjon i } \\
\text { Trondheim for } \\
\text { fylkets nærmeste } \\
\text { deler. }\end{array}$ \\
\hline Nord-Trøndelag & 5 & $\begin{array}{l}\text { Rørvik, Hegra, Meråker, } \\
\text { Verdal, Namsos. }\end{array}$ & 2 & $\begin{array}{l}\text { Steinkjer, } \\
\text { Levanger. }\end{array}$ \\
\hline Nordland & 9 & $\begin{array}{l}\text { Brønnøysund, Vensmoen } \\
\text { san. Fauske, Bodø, Nar- } \\
\text { vik, Vågan, Sortand, } \\
\text { Tysfjord, Ballangen. }\end{array}$ & 5 & $\begin{array}{l}\text { Sandnessjøen, } \\
\text { Mosjøen, Mo i } \\
\text { Rana, Meløy, } \\
\text { Buksnes (And- } \\
\text { øya forutsettes } \\
\text { sogne til Harstad } \\
\text { i Troms fylke) }\end{array}$ \\
\hline Troms . & 3 & $\begin{array}{l}\text { Harstad, Tromsø, Gibo- } \\
\text { stad. }\end{array}$ & 2 & Målselv, Skjervøy \\
\hline \multirow[t]{2}{*}{ Finnmark } & 5 & $\begin{array}{l}\text { Talvik, Vardø, Honnings- } \\
\text { våg, Vadsø, Kirkenes. }\end{array}$ & 1 & Hammerfest. \\
\hline & 86 & & 29 & \\
\hline
\end{tabular}

Da undertegnede tiltrådte som Statens tuberkuloseinspektør, var der 57 diagnosestasjoner i gang. Dette var meget utilfredsstillende av flere grunner:

1. 57 stasjoner var altfor få for landets behov.

2. I Nord-Norge hvor det er mest tuberkulose, var nøden på stasjoner relativt større enn sørpå.

3. Lægene betaltes pr. enkeltytelse, og dette bremset naturlig på de masseundersøkelser av miljøet som er nødvendig for å motarbeide tuberkulosen.

4. Det manglet en landsplan å arbeide etter.

Det vil nå formentlig interessere Tidsskriftets lesere å se hvor langt vi er kommet med en landsplan. (Se etterfølgende plan.)

$(\ldots)$

I Nord-Norge hvor det er mest tuberkulose, har vi fremdeles den største mangel på lungespesialister. Nord-Norge har jo også alltid vært stebarnet. Spesialistene klumper seg sammen, særlig i Oslo og Syd-Norge for øvrig. Dette kan ikke sies å svare til det hensyn vi skylder samfunnet.

Hva nå angår de planlagte stasjoner, så gjør tabellen ikke krav på å gi et fullstendig billede av hva der trenges av nye stasjoner, men tallet 29 stasjoner i tillegg til de 86 betegner et minimum, som vi foreløpig får stoppe opp ved.

Det vilde være ønskelig om unge læger med spesialutdannelse vil melde seg til tjeneste. 
S.W. Brochmann.

Publisert: 8. januar 2018. Tidsskr Nor Legeforen. DOI:10.4045/tidsskr.17.1035

(C) Tidsskrift for Den norske legeforening 2020. Lastet ned fra tidsskriftet.no 